Iva Vidović

Institut za povijest umjetnosti, Zagreb

\title{
Glinska utvrda i naselje od 18. do sredine 19. stoljeća prema kartografskim izvorima
}

\author{
Izvorni znanstveni rad - Original scientific paper \\ Primljen - Received 15. 6. 2021. \\ UDK 728.81:528.93(497.5Glina)"17/18" \\ DOI https://doi.org/10.31664/ripu.2021.45.13
}

\begin{abstract}
Sažetak
U radu se navode i analiziraju obilježja povijesno-prostornog razvoja Gline od njezina osnutka tridesetih godina 18. stoljeća izgradnjom bastionske utvrde na ušću rijeke Maje u Glinu, do sredine 19. stoljeća, kada je formirana osnovna urbana struktura mjesta sa svim svojim
\end{abstract}

vrijednostima na kojima počiva kulturnopovijesni i prostorni identitet današnjega grada. Razvoj Gline prati se na temelju poznatih i nekoliko dosad neobjavljenih kartografskih izvora.

Ključne riječi: Glina, utvrda, naselje, povijesno-prostorni razvoj, kartografski prikazi, 18. stoljeće, prva polovica 19. stoljeća

\section{Uvod}

Povijest današnjega grada Gline započinje tridesetih godina 18. stoljeća izgradnjom krajiške utvrde na ušću rijeke Maje u Glinu. Između utvrde na sjeveru i bedema na jugu, koji se protezao između tokova rijeka, razvilo se civilno naselje na čijoj osnovnoj prostornoj organizaciji počiva i današnji grad. Ubrzo nakon izgradnje, zbog gubitka obrambene uloge i jačanja civilnih funkcija naselja, utvrda i bedem postupno se zapuštaju da bi se do sredine 19. stoljeća u potpunosti zanemarili i većim dijelom razgradili unutar urbane strukture mjesta. Od najranijega intenzivnijeg znanstveno-istraživačkog bavljenja sveobuhvatnom poviješću Gline osamdesetih godina 20. stoljeća do danas, istraživanje njezina povijesnoprostornog razvoja bilo je vrlo skromno. ${ }^{1}$ Stoga je cilj ovog teksta, uz pomoć kartografskih izvora, proširiti i upotpuniti znanja o gradnji utvrde i razvoju glinskog naselja zaključno s vremenom kada je formirana osnovna urbana struktura i kulturnopovijesne vrijednosti ključne za identitet današnjega grada. Nova saznanja dobivena proučavanjem vrijednih kar- tografskih dokumenata mogu poslužiti kao korisno ishodište za buduća povijesna i povijesnoumjetnička istraživanja, kao što se mogu primijeniti i prilikom obnove kulturnopovijesne cjeline grada stradale u nedavnom potresu na Banovini. Rad ne donosi pregled svih kartografskih prikaza Gline od izgradnje utvrde do sredine 19. stoljeća, nego samo onih na kojima je prvi put uočljiva značajnija promjena u prostornom i graditeljskom razvoju.

\section{Glinska utvrda i okolica u prvoj polovici 18. stoljeća}

Čitavo područje današnje Banovine, kao i većina teritorija kontinentalne Hrvatske, od kraja 15. stoljeća razvija se u nestabilnim uvjetima čestih ratnih razaranja u sklopu osmanskih osvajačkih pohoda. ${ }^{2}$ Konačna prekretnica u raspodjeli vojnog utjecaja Habsburške Monarhije i Osmanskog Carstva, a samim time i u razvoju Hrvatske, bit će omogućena velikom pobjedom Habsburgovaca u Drugoj bitci kod Beča 1683. godine nakon koje je uslijedio niz uspješnih oslobodilačkih 
ratnih operacija. Do kraja stoljeća od osmanske vlasti oslobodit će se značajan dio hrvatskog teritorija čija će nova granica na Uni i Savi biti potvrđena mirom u Srijemskim Karlovcima 1699. godine. ${ }^{3}$ Nakon oslobođenja vojno-krajiško uređenje proširuje se na sve novooslobođene prostore, dok jedinu iznimku čini područje između Kupe i Une na kojemu se 1704. godine formira Banska generalkomanda, područje u gospodarskom i financijskom pogledu pod nadzorom Dvorske komore u Beču, a u upravom pogledu pod zapovjedništvom hrvatskog bana i staleža. U skladu s novim prilikama težište obrambenih zadataka premješta se na novu graničnu frontu koju je potrebno učvrstiti obnovom postojećih i izgradnjom novih, modernijih utvrda.

Na području Banske krajine, u pozadini ratne granice između Une i Kupe, neposredno nakon Karlovačkog mira nema značajnije graditeljske aktivnosti. ${ }^{4}$ Sjedište Glinske kapetanije, upravnog i crkvenog života glinskog kraja, bilo je u Svračici (Szrachicza), starome feudalnom središtu i utvrdi smještenoj na lijevoj obali Maje, na brdu iznad današnjeg naselja Svračica. ${ }^{5}$ Naime, u to vrijeme na području današnjega grada Gline nalazi se prazna močvarna ravnica. Razvoj naseljenosti glinskog kraja, čiji se kontinuitet može pratiti od početka 13. stoljeća, naglo je prekinut silnim osmanskim pustošenjima sredinom 16. stoljeća. ${ }^{6}$ Iako je taj kraj bio naseljen od 13. stoljeća i iako se toponim Glina relativno često pojavljuje $\mathrm{u}$ pisanim povijesnim izvorima srednjega i ranoga novog vijeka, na položaju današnjeg grada nije postojalo starije naselje. Ime Glina redovito označava rijeku, njezino okolno područje ili nekakav posjed, a ne naselje, utvrdu ili kaštel toga imena. ${ }^{7}$ Prema tome, povijest današnjega grada započinje tek u 18. stoljeću izgradnjom banske krajiške utvrde kada se i ime Glina, vezano uz utvrdu, a kasnije i uz naselje, počinje pojavljivati u kartografskim izvorima.

Oružani sukobi i napeti odnosi između Habsburške Monarhije i Osmanskog Carstva nastavljaju se i u 18. stoljeću. Prvi rat izbija 1716. godine i već nakon dvije godine završava mirovnim sporazumom u Požarevcu prema kojemu Habsburška Monarhija dobiva brojna nova područja, uključujući i desnu obalu Une. Zbog toga veoma nepovoljnog sporazuma za Osmanlije, napetosti na hrvatskom pograničnom području se nastavljaju. Sve izglednija mogućnost novog rata potiče hrvatske zemlje i unutrašnjoaustrijske staleže da dodatno ojačaju obrambenu sposobnost Vojne krajine učvršćivanjem novoformirane prve pogranične linije obrane i njezine pozadinske ratne baze. Radi zaštite područja Banske krajine Hrvatski sabor 1733. godine donosi odluku o obnovi banskih utvrda, a za organizaciju radova zadužuje zapovjednike Kostajničke, Dubičke, Jasenovačke i Glinske kapetanije. ${ }^{8}$ Zbog molbe hrvatsko-slavonsko-dalmatinskog bana Josipa Esterházya upućene caru Karlu za slanje iskusnoga graditelja utvrda, na pogranično područje Banske krajine dolazi francuski graditelj Du Portal de Monteau koji nakon obilaska terena u ljeto 1735 . godine predlaže položaj izgradnje nove krajiške utvrde na ušću rijeke Maje u Glinu, čime započinje povijest današnjega grada Gline. ${ }^{9}$

Da je izgradnja krenula vrlo brzo i da je velik dio radova na utvrdi i ostalim fortifikacijskim strukturama bio obavljen sredinom 1736. godine, može se iščitati iz banove naredbe iz svibnja kojom traži kapetana Glinske kapetanije da se s većinom vojne posade premjesti u novoizgrađenu utvrdu u Glini, jer se u njoj može sasvim pristojno stanovati i djelovati. ${ }^{10}$ Idućih godina građevinska aktivnost u Banskoj krajini stagnira zbog ulaska Habsburške Monarhije u novi rat $s$ Osmanlijama u kojemu će doživjeti brojne poraze i izgubiti većinu područja stečenih prijašnjim Požarevačkim mirom. ${ }^{11}$ Zbog novih ratnih okolnosti, u glinskoj utvrdi 4. rujna 1737. godine održana je sjednica Hrvatskog sabora. ${ }^{12}$ Prema tom podatku može se zaključiti da je utvrda u Glini tada velikim dijelom bila završena i služila svojoj obrambenoj namjeni. Sve od završetka rata 1739. pa do 1745 . godine, kada će se ponovo pokrenuti opsežniji radovi na utvrdi, građevinska aktivnost svest će se na održavanje i vjerojatno izgradnju upravnih i stambenih građevina unutar tijela utvrde.

Plan iz 1744. godine jedan je od najstarijih prikaza glinske utvrde i njezine okolice u prvom desetljeću postojanja (sl. 1). ${ }^{13}$ Može se pretpostaviti da je izrađen u sklopu radova koji će se izvoditi 1745 . godine, a koji su predviđali obnovu i učvršćenje utvrde, izgradnju novih vojnih građevina unutar bedema te preuređenje okolice u svrhu pojačanja obrambene funkcionalnosti cijelog prostora. Radove nije predvodio $\mathrm{Du}$ Portal, nego novi graditelj Banske krajine Laurentius Grynseysen. ${ }^{14}$ Taj plan nije prikaz stvarnog stanja iz tog vremena s obzirom na to da će neki od ucrtanih elemenata biti izvedeni tek kasnije, a od realizacije ostalih će se odustati. No utvrda u to vrijeme sigurno ima svoj prepoznatljiv oblik. Nalazi se na području s triju strana okruženim i zaštićenim vodom, između meandara rijeke Gline i njezinoga desnog pritoka Maje. Malih je dimenzija i jednostavnoga, ali atipičnog tlocrta u odnosu na općenite zakonitosti bastionskog graditeljstva. ${ }^{15}$ Osnovno tijelo utvrde čini pravokutnik s neznatno izduljenim stranicama u smjeru sjever-jug, dok se bastioni nalaze na središtima stranica, a ne na uglovima pravokutnika. Neuobičajene ideje graditelja Du Portala, osim u položaju bastiona, očituju se i u položaju ulaza u utvrdu koji se nalazi na sjevernoj fasi istočnog bastiona, a ne na kurtini. Na planu je prikazano i nekoliko objekata unutar bedema, no ne može se sa sigurnošću reći radi li se o budućoj izgradnji ili o starijim postojećim građevinama. Oko utvrde je šanac koji se na sjevernoj strani puni vodom iz rijeke Gline. Neposredno ispred ulaza u utvrdu nalazi se raskrižje s tri kraka: sjeverozapadnim koji je mostom vodio preko šanca i rijeke Gline prema Topuskom i Karlovcu, južnim koji je vodio prema Dvoru i Kostajnici te istočnim krakom koji je preko rijeke Maje vodio prema Petrinji i Sisku.

Cijelo područje zatvara bedem izgrađen između meandara dviju rijeka južno od utvrde. Na uglovima ima redute, a između njih trokutaste istake razmještene u gotovo jednakim razmacima. Prema novijim kartografskim prikazima može se zaključiti da su u prvoj fazi izgradnje bedema ostvarene samo redute i središnji trokutasti istak. Jedina izgradnja izvan utvrde, a unutar prostranog zaštićenog prostora, nalazi se na istoku uz prometni pravac Glina - Sisak i rijeku Maju. Riječ je o nekoliko objekata jednostavnih pravokutnih tlocrta prostorno odvojenih u dvije grupe. Objekti grupirani uz Maju vjerojatno su predviđeni za stambenu namjenu s obzirom na 


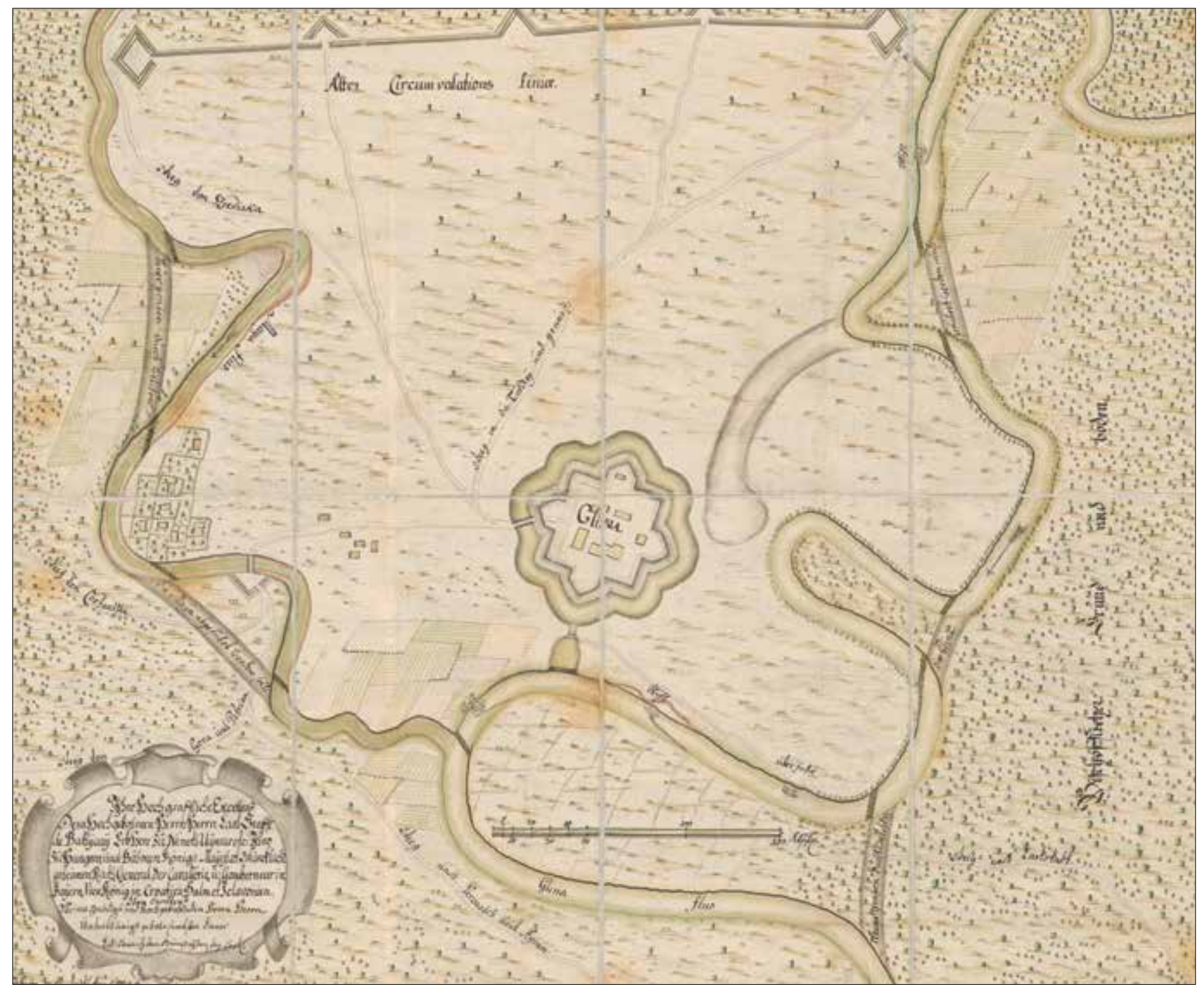

1. Plan Gline, 1744. (Österreichische Nationalbibliothek, Wien)

Map of Glina, 1744

to da su se nalazili unutar dvorišta kojima je pridružen vrt. Iako se ne može odrediti radi li se o postojećoj ili planiranoj gradnji, važna je činjenica da se već u to vrijeme javlja potreba za stvaranjem zasebnog naselja izvan bedema utvrde.

Sredinom 18. stoljeća provodi se temeljita reorganizacija Vojne krajine kojom ona prestaje funkcionirati kao obrambena institucija osnovana ponajprije kao zaštita od Osmanlija i počinje služiti za ispunjavanje raznih političkih i vojnih ciljeva Habsburške Monarhije. ${ }^{16}$ Godine 1745. Banska krajina dijeli se na dvije graničarske pukovnije: Prvu bansku pukovniju sa sjedištem u Kostajnici i Drugu bansku pukovniju sa sjedištem u Glini. ${ }^{17}$ Prestanak neposredne osmanske opasnosti i namjera Habsburške Monarhije da u Vojnoj krajini stvori uvjete u kojima bi se ona u što većoj mjeri samostalno uzdržavala, utjecalo je pozitivno na razvoj vojno-civilnih naselja i gradova. Upravo u to vrijeme nastaje plan Gline kojim je osmišljen položaj i osnovna prostorna organizacija budućeg naselja (sl. 2). ${ }^{18}$
Prema planu stambeno je naselje, previđeno za krajišnike, njihove obitelji i manji broj civilnog stanovništva, smješteno uz bedem južno od utvrde. Dužina naselja određena je tokovima rijeka, a širina pružanjem bedema i širokog pojasa močvarnog tla koje se nalazi uz utvrdu. Podijeljeno je dvjema kraćim i širim ulicama u smjeru sjever-jug i dvjema dužim i užim ulicama u smjeru istok-zapad. Unutar naselja neujednačeno su raspoređeni mali stambeni objekti pravokutnog tlocrta s dvorištima. S obzirom na to da plan ne prikazuje postojeće stanje, nego buduću izgradnju, ne može se sa sigurnošću odrediti koji su dijelovi naselja već tada postojali. No može se zaključiti da je određen broj stambenih jedinica već bio izgrađen, ako se uzme u obzir činjenica da su kuće vidljive i na starijem prikazu glinske utvrde i okolice (1744.), kao i podatak da je Glina u to vrijeme proglašena jednim od dvaju glavnih vojnih i upravnih sjedišta cijele Banske krajine. Drugo manje stambeno područje nalazi se na već spomenutom dijelu uz rijeku Maju, istočno od utvrde. Svi 


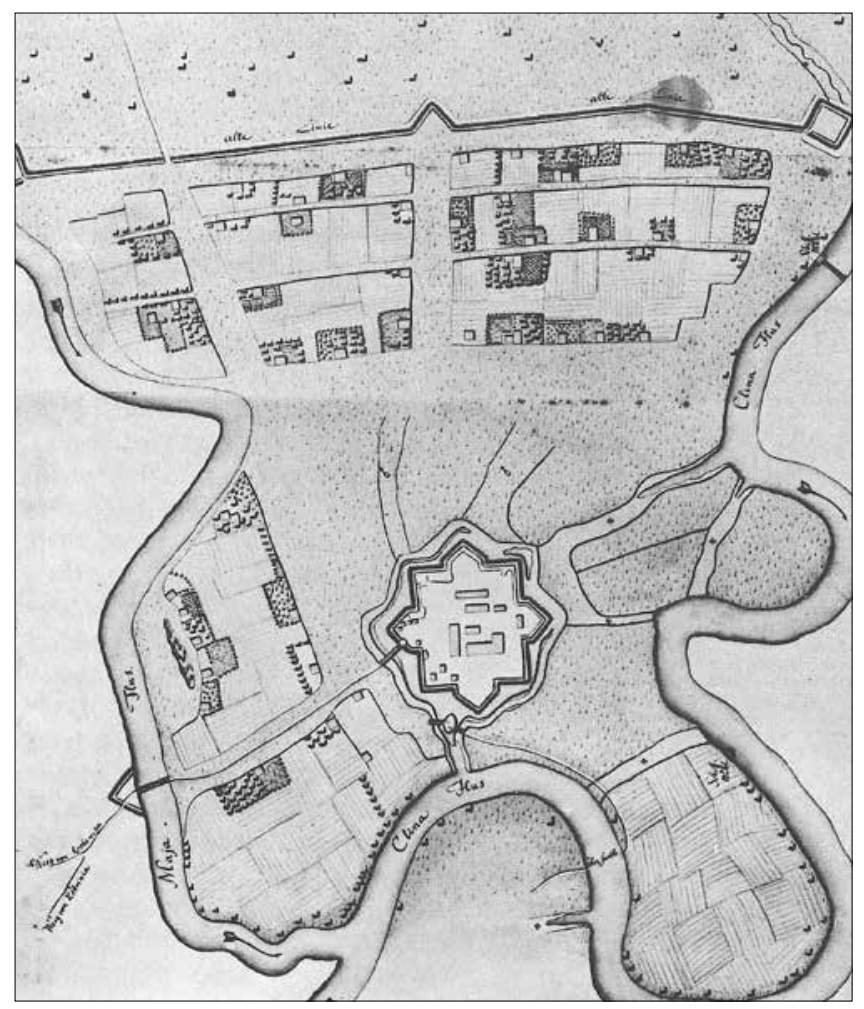

2. Plan Gline, 1750. (Österreichisches Staatsarchiv, Kriegsarchiv, Wien)

Map of Glina, 1750

objekti vojne i upravne namjene smješteni su unutar utvrde čiji su obrisi iscrtani jednako kao i na starijem planu iz 1744. godine. Za razliku od tog plana, na ovom bedem sadrži dva rubna revelina i tek jedan središnji trokutasti istak.

Iako je na planu Gline iz 1750. godine utvrda prikazana idealizirano, a tokovi rijeka veoma pojednostavljeno te se ne može sa sigurnošću odrediti što je od prikazanog već postojalo, a što će se tek izgraditi, vrijednost plana za proučavanje povijesno-prostornog razvoja grada ne može se osporiti. Naime, prvi put prikazuje glinsko naselje, njegov položaj i osnovni oblik na kojemu počiva buduće naselje gradskih osobina, pa i današnji grad.

\section{Glina na kartama Banske krajine iz druge polovice 18. stoljeća}

Razvojni procvat Glina doživljava tijekom druge polovice 18. stoljeća. Tada se doseljava velik broj novog stanovništva koje svojom obrtničkom i trgovačkom djelatnošću zadovoljava razne potrebe rastućeg broja vojnika naseljenih u okolici utvrde. Da bi se unaprijedila obrtnička djelatnost, a obrtnici djelotvornije organizirali, diljem cijele Vojne krajine od sredine šezdesetih godina hrvatsko-ugarska kraljica i rimsko-njemačka carica Marija Terezija dodjeljuje opće cehovske privilegije. Nakon Karlovačkoga, Slavonskoga i Varaždinskoga generalata, cehovske privilegije dodijeljene su i Banskoj krajini 1773. godine. ${ }^{19}$ Glavno sjedište i središte velikog ceha za cijelo područje bila je Petrinja, dok su se u Kostajnici, Vojnom Sisku, Glini i Dubici nalazila filijalna cehovska odijeljena. ${ }^{20}$ Iako su privilegije Banskoj krajini u odnosu na ostale generalate na području Hrvatske dodijeljene relativno kasno, može se pretpostaviti kako je obrtnička djelatnost u Glini postojala i ranije. Osamdesetih godina u Glini su postojali cehovi kovača, stolara, pekara, bravara, remenara i sedlara, a kasnije su uz njih u cehove organizirani mlinari, lončari, bačvari, brijači, mesari, urari, dimnjačari i $\mathrm{dr}^{21}$

U svrhu dodatnog jačanja, ali i kontrole obrta i trgovine, bečki dvor tijekom druge polovice 18 . stoljeća veća trgovišta Vojne krajine proglašava vojnim komunitetima, odnosno povlaštenim krajiškim gradovima. ${ }^{22}$ Gradovi koji su imali status vojnog komuniteta bili su specifično organizirani i uživali su povlastice koje su omogućavale intenzivniji razvoj njihovih privrednih djelatnosti. ${ }^{23} \mathrm{U}$ Banskoj krajini takav status imale su Petrinja i Kostajnica, dok je Glina ostala samo trgovište, iako su postajali prijedlozi da se proglasi vojnim komunitetom. ${ }^{24}$ Bez obzira na to, status trgovišta i mogućnost održavanja tjednih sajmova, kao i razvijena obrtnička djelatnost, povoljno su utjecali na njezin prostorni i demografski razvoj.

Kako je Glina napredovala nakon sredine 18. stoljeća, vidljivo je na kartama Banske krajine izrađenim između 1773. i 1775. (sl. 3) ${ }^{25}$ te između 1776. i 1784 . godine (sl. 4). ${ }^{26} \mathrm{Na}$ obje karte glinsko naselje prikazano je vrlo slično, dok se prikazi utvrde i njene uže okolice razlikuju. Osnovni pravokutni oblik naselja, predviđen i na planu iz 1750. godine, određen je tokovima rijeka na istoku i zapadu, bedemom na jugu i močvarnim pojasom na sjeveru. Možemo vidjeti da se tijekom druge polovice 18. stoljeća formira ortogonalna shema naselja na kojoj počiva povijesna jezgra današnjega grada. Gotovo pravilni ortogonalni sustav čini pet kraćih komunikacija u smjeru sjever-jug i četiri dulje u smjeru istok-zapad. Unutar blokova različitih veličina smještene su brojne kuće jednostavnih pravokutnih tlocrta i većinom zabatima orijentiranima na ulicu. Vjerojatno se radilo o drvenim objektima, prizemnicama ili katnicama s gospodarskim dvorištem i dvorišnim zgradama, a gradili su ih krajišnici i civilno stanovništvo. ${ }^{27}$ Najveća gustoća izgrađenosti nalazila se uz dvije najvažnije ulice koje su od raskrižja ispred utvrde poprečno prolazile naseljem i izlazile kroz otvore $u$ bedemu istočno i zapadno od središnjega trokutastog istaka. Istočna prometnica (današnja Hrvatska ulica) bila je glavna ulica naselja, a kao i danas, nastavljala se na prometnicu koja povezuje Glinu s Dvorom. Druga važna ulica naselja, formirana sredinom druge polovice 18. stoljeća, protezala se dijagonalno od raskrižja i spajala na današnju Ulicu kneza Branimira. Neposredno nakon izlaska kroz bedem račvala se na dva kraka, južni prema okolnim selima i zapadni prema Topuskom i Karlovcu preko novog prijelaza na rijeci Glini. $\mathrm{Na}$ obje karte ucrtana je i zidana katolička kapela sv. Ivana Nepomuka podignuta 1769 . godine,$^{28}$ a čijom će se izgradnjom upravo na praznom prostoru između dijagonalne i glavne ulice nagovijestiti težnja prostornog povezivanja naselja i utvrde. Pravoslavna drvena kapela sv. Đurđa smje- 


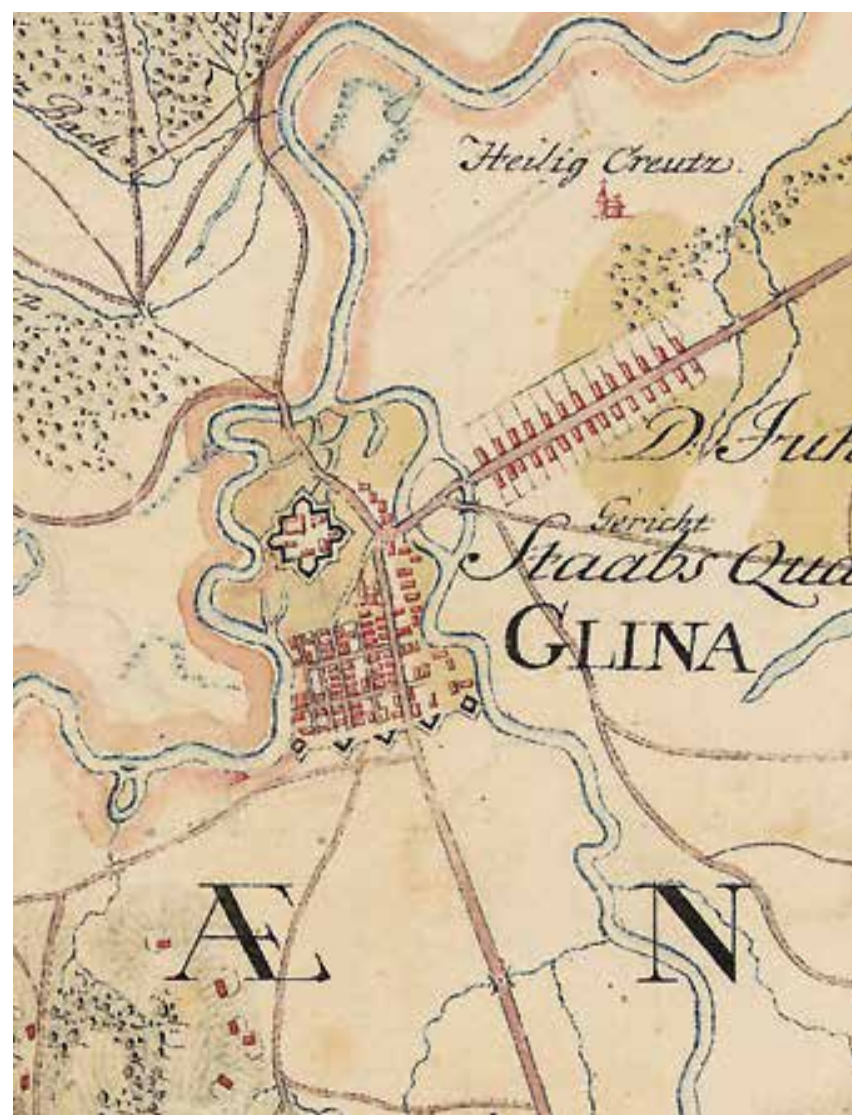

3. Glina na karti Banske krajine, 1773. - 1775. (Österreichische Nationalbibliothek, Wien)

Glina on the map of the Banal Frontier, 1773-1775

štena je unutar jednog od južnih blokova uz bedem. Iako je zasigurno već izgrađena u drugoj polovici 18. stoljeća, kao i zgrada prve škole u Glini koja je otvorena već 1764 . godine, ona nije prikazana na spomenute dvije karte. ${ }^{29}$

Razlike u navedenim kartama, što se tiče glinskog područja, prisutne su jedino u prikazu utvrde i uže okolice. Na starijoj izrađenoj karti, kao i na svim prijašnjim planovima, utvrda je iscrtana u svom idealnom tlocrtom obliku, dok su na novijem prikazu linije njezinih bedema izmijenjene i više ne tvore pravilnu strukturu. S obzirom na to da je u cijelosti građena od zemlje i drveta, da bi zadržala izvorni oblik, utvrda je zahtijevala sustavno održavanje, s čime se izgleda posustalo već u drugoj polovici 18. stoljeća. Samo na novijoj karti na sjeverozapadnoj strani utvrde ucrtan je prolaz koji je vodio do slobodne zelene površine, vjerojatno vrta pukovnika, koja će se kasnije pretvoriti u šetalište zvano Oberstarija.

O naglom i iznenadnom razvoju Gline u drugoj polovici 18. stoljeća svjedoči i plan širenja iz 1780. godine (sl. 5). ${ }^{30} \mathrm{Zbog}$ značajnog povećanja broja vojnog i civilnog stanovništva, čije je potrebe bilo teško zadovoljiti unutar postojećih gabarita naselja, izrađuje se plan širenja u dvije varijante južno od bedema. Prema obje varijante, A i B, novi vojni i javni objekti formirali bi se u pravilnim blokovima oko središnjeg trga. Složenija i veća varijanta A u velikoj mjeri podsjeća na

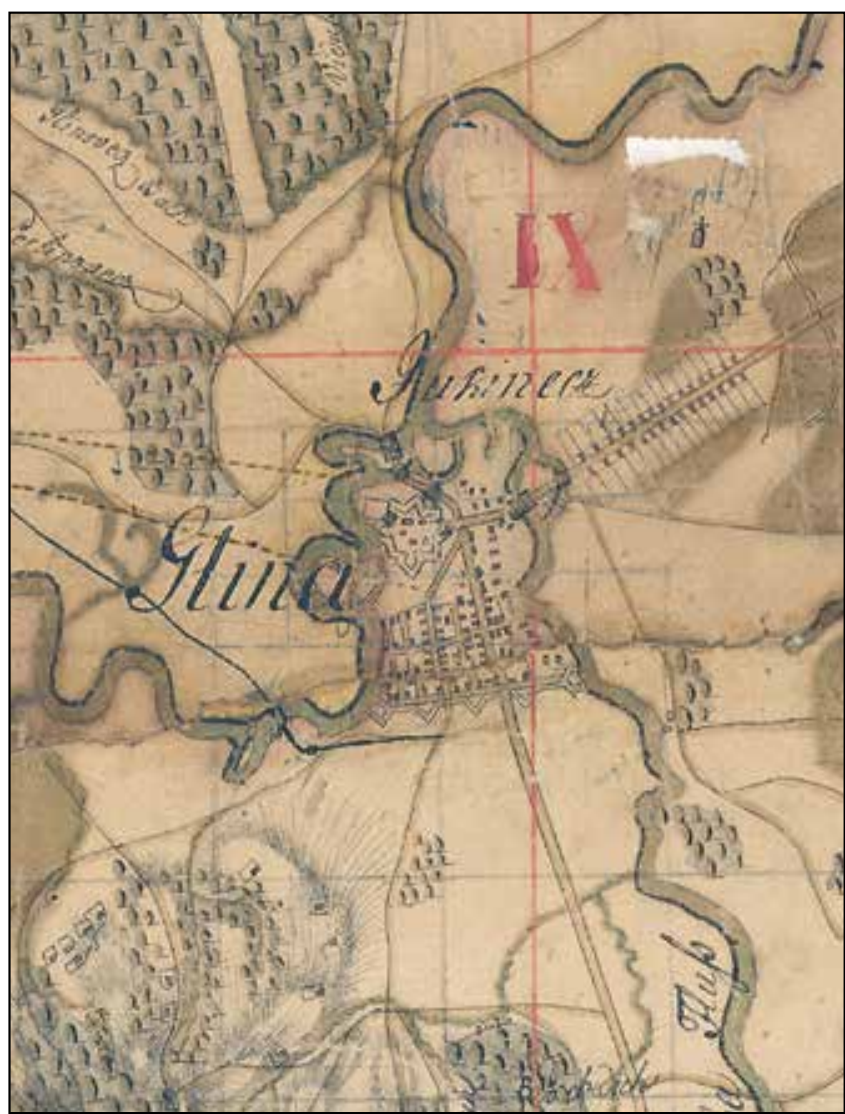

4. Glina na karti Banske krajine, 1776. - 1784. (Hrvatski državni arhiv, Zagreb)

Glina on the map of the Banal Frontier, 1776-1784

Bjelovar, također novoosnovano krajiško naselje 18. stoljeća. Nijedan plan nije ostvaren, a svi potrebni vojni sadržaji i stambene jedinice interpolirane su u postojeću strukturu naselja. Banska krajina nije imala dovoljne financijske mogućnosti da u Glini ostvari navedene planove. ${ }^{31}$

Iz navedenih prikaza vidljivo je da se Glina tijekom 18 . stoljeća nije razvijala kao tipični krajiški grad koji određuje pravilna struktura ulica s naglašenim ključnim urbanim točkama, kao što su gradski trg s grupiranim osnovnim upravnim, javnim i vojnim objektima te središnji položaj katoličke crkve. Glina je nastala širenjem na jedinome dostupnom branjenom prostoru, čiji su pravokutni oblik odredili tokovi rijeka i bedem. Osnovni sadržaji naselja smješteni su na različitim mjestima diljem naselja i unutar utvrde, a ključne urbane točke čine utvrda i bedem. Tijekom 18. stoljeća Glina je prešla značajan razvojni put od male krajiške utvrde važnoga strateškog značenja do sasvim novog naselja koje je u samo par desetljeća poprimilo gradske osobine.

\section{Glina u prvoj polovici 19. stoljeća}

Kontinuirani gospodarski, demografski i prostorni rast Gline nastavlja se tijekom prve polovice 19. stoljeća. Kratko vrijeme nakon austrijsko-francuskog rata čitavo područje 


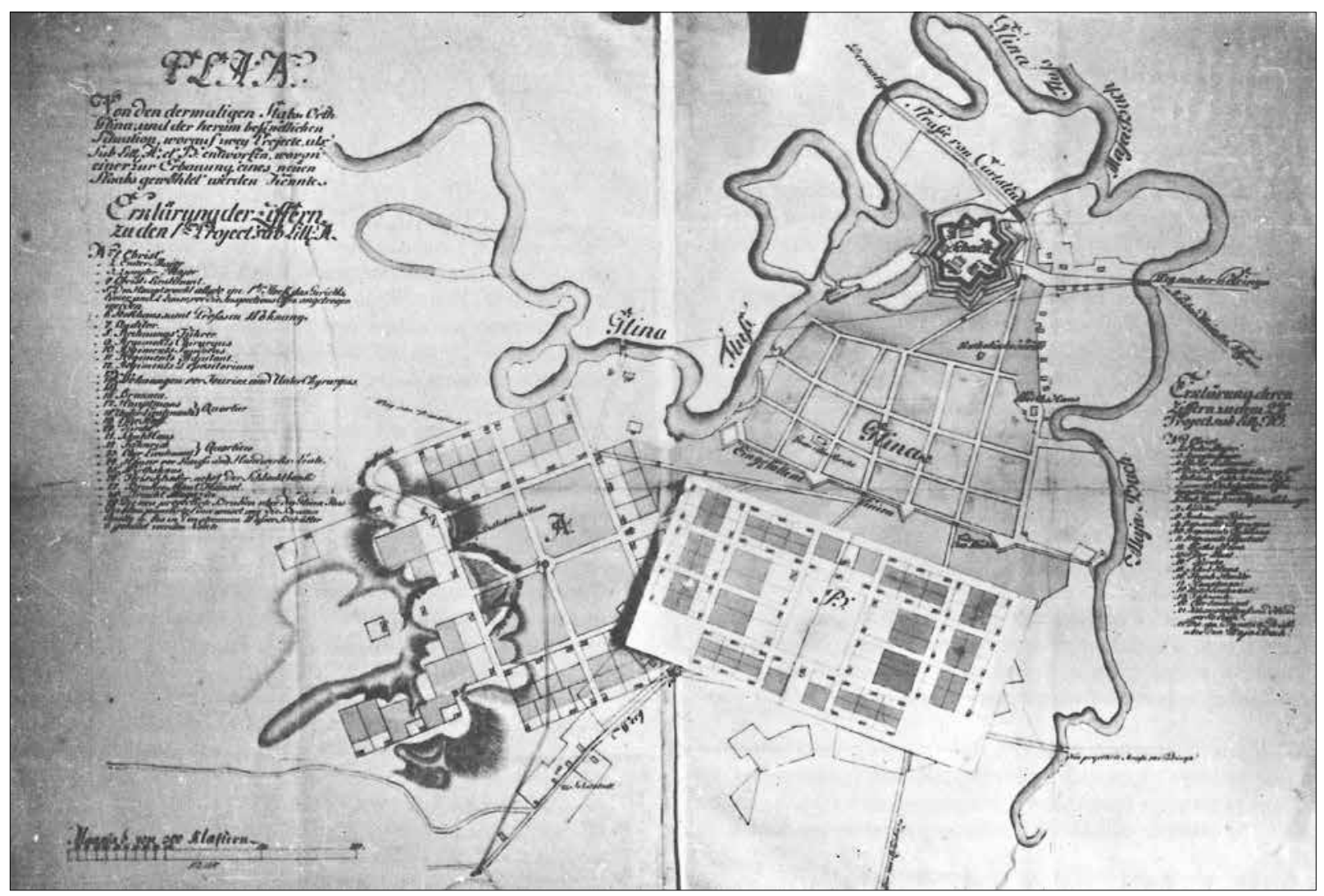

5. Plan Gline i projekt nove izgradnje u dvije varijante (A i B), 1780. (Österreichisches Staatsarchiv, Kriegsarchiv, Wien) Map of Glina and new construction plans in two variants (A and B), 1780

Banske krajine, kao i ostali dijelovi civilne i vojne Hrvatske između Save i mora, od 1809. do 1813. godine postaje dio Ilirskih pokrajina. U novopripojenim hrvatskim i slovenskim zemljama Francuzi su nastojali provoditi modernizaciju sudstva, uprave i školstva, kao i ulagati u razvoj trgovine, poljodjelstva i izgradnju prometnica. No njihova kratkotrajna uprava na području Gline nije ostavila mnogo tragova na prostorni i građevni razvoj mjesta. Što se sve promijenilo u urbanoj strukturi Gline na prijelazu iz 18. u 19. stoljeće te tijekom i nakon francuske uprave, prikazano je na planu iz 1821. godine (sl. 6). ${ }^{32}$

$\mathrm{S}$ utvrdom u središtu prikaza, taj je plan nastao s ciljem pregleda starih i novih vojnih sadržaja u naselju, dok je od stambenih dijelova obuhvaćen samo niz sjevernih blokova. Utvrda i pozadinski prostor i dalje su zvjezdolikim šancem te dovodnim i odvodnim kanalima prostorno izolirani od ostatka brzorastućega naselja. Međutim, razgradnjom dijela jugoistočnoga zemljanog bedema utvrde i njezinim otvaranjem prema okolnom prostoru, započinje bitan proces spajanja cijelog prostora u jedinstvenu novu urbanu strukturu. Vojni kompleks sve se više širi izvan bedema utvrde i grupira uz fronte ulica koje omeđuju budući središnji gradski park. Unutar utvrde smještena je zgrada glavnog stožera i ureda pukovnije (danas Općinski sud), kapelnikov i zapovjednikov stan, vojna kuhinja i štala. Duž današnje Hrvatske ulice nalazili su se ured revizora, stan glavnoga graditelja i škola, a uz južni potez budućeg parka stan župnika, župni dvor i narodna gostiona (danas Hotel Casino). ${ }^{33}$ Većinom se radilo o zidanim građevinama podignutima na prijelazu iz 18. u 19. stoljeće. Na zapadnom dijelu prostranog područja južno od utvrde nalazila se štala i sjenik te prazan prostor namijenjen za razna vojna događanja (Paradeplatz), dok se na istočnom dijelu nalazila stara kapela i dijagonalno položena prometnica koja je spajala naselje s putom za Petrinju. Hortikulturno uređenje novoga središnjeg prostora, koji zadobiva vojni i civilni karakter, odvija se najintenzivnije u vrijeme francuske uprave. ${ }^{34}$ Tada se sadnjom drveća u blizini katoličke kapele započinje oblikovati današnji središnji park. Za vrijeme ili neposredno nakon francuske vladavine dolazi do širenja civilnog naselja izvan bedema uz novu glavnu cestu prema Karlovcu (Carlstadter Gasse, današnja Ulica kralja Tomislava), što je vidljivo na karti Banske krajine iz 1818. godine (sl. 7). ${ }^{35}$ Iako je početak 19. stoljeća u Glini obilježen brojnom novom izgradnjom vojnog karaktera, strateška i obrambena uloga mjesta uvelike je oslabila. Širenje naselja prema jugu, početak rušenja bedema utvrde i bedema između rijeka svjedoče o sve većem jačanju njezinih civilnih funkcija.

Morfološka i funkcionalna struktura Gline nastavit će se oblikovat pod jednakim uvjetima i obilježjima čitavu prvu polovicu 19. stoljeća. Veoma dinamična zbivanja u njezinom prostornom razvoju zabilježena su na planu iz 1860. godine (sl. 8). ${ }^{36}$ Vidna promjena u urbanoj strukturi uočljiva je na 


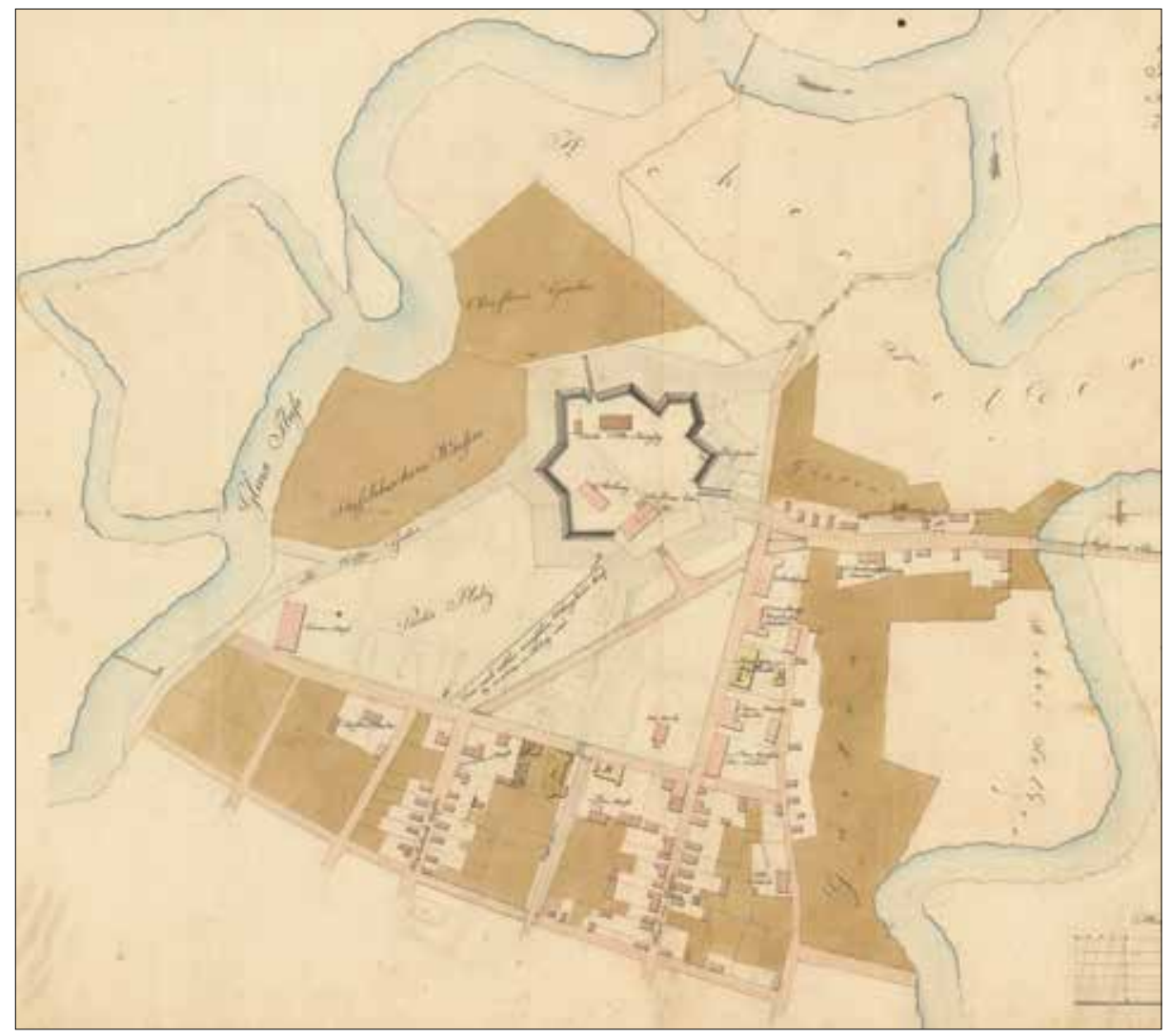

6. Plan Gline, 1821. (Hrvatski državni arhiv, Zagreb)

Map of Glina, 1821

prostoru južno od utvrde koji se pretvara u novo središte oblikovanjem parka, važne prostorne poveznice između utvrde i naselja. Sadnja platana unutar parka odvija se na poticaj tadašnjeg pukovnika Glinske regimente Josipa Jelačića, u čije se vrijeme regulira i cesta koja se protezala dijagonalno od utvrde do naselja. ${ }^{37} \mathrm{Od}$ tog vremena pa do danas cesta u luku obgrljuje sjeverni dio parka i nastavlja se na današnju Ulicu Antuna i Stjepana Radića, a ne na Ulicu kneza Branimira kako je to bilo u 18. stoljeću. Uza zapadni rub parka, uz spomenutu cestu, krajem prve polovice 19. stoljeća izgrađen je niz novih zidanih zgrada. Radilo se o stambenim kućama pukovnika (danas Katastarski ured), dopukovnika i majora, s dvorištima i gospodarskim objektima. Nova izgradnja prisutna je i na suprotnome, istočnom rubu parka gdje se 1824 . godine započinje graditi nova katolička crkva sv. Ivana Nepomuka. ${ }^{38}$ Izradio ju je tada vodeći zagrebački graditelj Bartol Felbinger u klasicističkom stilu. ${ }^{39}$ Starija kapela iz 1769 . služi kao župna crkva od 1800. godine, kada se sjedište glinske župe iz Svračice premješta u Glinu. Srušena je nakon posvećenja nove crkve 1830. godine. Sjeverno od parka nasipavanjem dijela šanca i još većom razgradnjom bedema utvrde nego početkom 19. stoljeća, dolazi do vizualnoga i funkcionalnog spajanja dvaju prostora. Uza svu spomenutu stariju i noviju izgradnju, glinski park krajem prve polovice 19. stoljeća, kao skladna prostorna poveznica utvrde i naselja, postaje važno okupljalište i jedna od ključnih urbanih točaka u mjestu.
Kako je vidljivo na planu, stambeni dio naselja nastavlja se razvijati unutar starog rastera ulica pretežno uz današnju Branimirovu (Griechische Gasse), ${ }^{40}$ Hrvatsku ulicu (Zirovacer Gasse) te uz prometnice na jugu, uz današnju Tomislavovu i Ulicu žrtava Domovinskog rata. Značajno širenje naselja prema jugu omogućeno je konačnim rušenjem bedema čiji su preostali tragovi čitljivi iz parcelacije. ${ }^{41}$ Od 1803. do 1850. godine broj stanovnika Gline porastao je sa 764 na 2166 stanovnika ${ }^{42}$ Ipak, taj značajan i brz rast nije išao u korak $s$ rastom broja stambenih objekata. Razlog tomu može se pronaći u činjenici da su tada u Glini brojne starije drvene kuće zamjenjivane novim, prostranijim i zidanim objektima, u kojima je živjelo više ljudi i čije su se prostorije često iznajmljivale. ${ }^{43}$ Većinom se radilo o kućama pravokutnog tlocrta ili tlocrta u obliku slova "L", s gospodarskim objektima u dnu izduljenih dvorišta. ${ }^{44}$

Uz formiranje središnjeg parka, druga značajna promjena u urbanoj strukturi uočljiva je na potezu današnje glavne glinske ulice (Ulica Antuna i Stjepana Radića). Protočnost na sjeveru dobiva regulacijom prometnice uz park, a na jugu rušenjem bedema. Zbog slabe protočnosti ulica je sve do četrdesetih godina bila graditeljski zanemarena, što je pak omogućilo njezino širenje i lakšu prilagodbu novoj ulozi središnje ulice u kojoj će se formirati šetalište i izgraditi građevine namijenjene važnim društvenim ulogama. $\mathrm{Na}$ njezinom južnom kraju spajanjem nekadašnjih ulica, koje su 


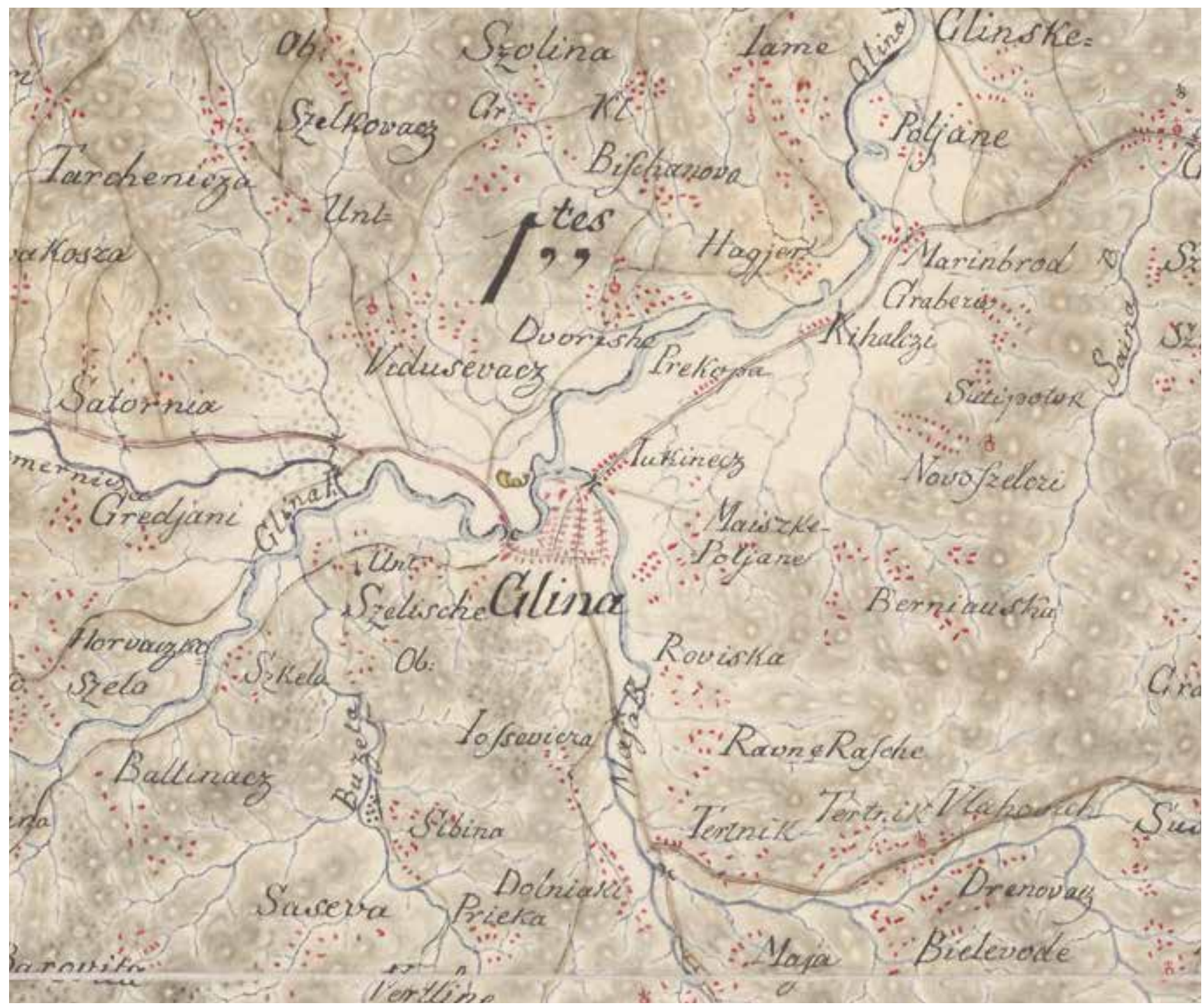

7. Glina na karti Banske krajine, 1818. (Österreichische Nationalbibliothek, Wien)

Glina on the map of the Banal Frontier, 1818

se nalazile neposredno unutar i izvan bedema, spontano se oblikovao manji trg koji danas služi kao prometno čvorište. Uz istočni rub ulice 1827. godine izgrađena je nova zidana pravoslavna crkva Rođenja Bogorodice, koju je također projektirao B. Felbinger. ${ }^{45}$

Prva polovica 19. stoljeća u Glini obilježena je gospodarskim i demografskim rastom, koji će povoljno utjecati na razvoj mjesta. Obrambene strukture u potpunosti gube na važnosti i razgrađuju se unutar nove prostorne organizacije u kojoj se ističu park s okolnim novim izgradnjama i katoličkom crkvom, te nova glavna ulica sa svratištem i pravoslavnom crkvom. Zbog prostorne izdvojenosti parka od civilnog naselja, kao i raštrkanog položaja sakralnih, vojnih i upravnih objekata, Glina se i dalje nije ubrajala u tipične vojnokrajiške gradove. Njezina glavna posebnost i razlike u odnosu na ostale vojnokrajiške gradove i naselja proizišli su iz specifičnog geomorfološkog i krajobraznog konteksta razvoja.

\section{Umjesto zaključka}

Iako se zbog jednostavnog oblikovanja i malih dimenzija ne može ubrojiti u značajna ostvarenja bastionskog graditeljstva, glinska je utvrda od ključne važnosti za povijest današnjega grada. Položaji utvrde i bedema odredili su mjesto nastanka i oblik naselja na čijemu osnovnom rasteru ulica, kao i osnovnim prometnicama, počiva i današnji grad. Neizostavan dio kulturnopovijesnog identiteta današnje Gline čini i gradski park, čija vrijednost i specifičnost prije svega proizlazi iz lokacije i funkcije poveznice naselja s utvrdom, a zatim iz kulturnih i estetskih obilježja. Uočavanje tih bitnih povijesnih razvojnih elemenata u današnjoj slici grada uvelike je otežano novom izgradnjom iz 20. stoljeća, koja je bitno izmijenila strukturu prostora. Od utvrde nisu ostali nikakvi materijalni tragovi, niti se može uočiti njezin nekadašnji položaj koji je u potpunosti negiran izgradnjom stambenih objekata i nove 


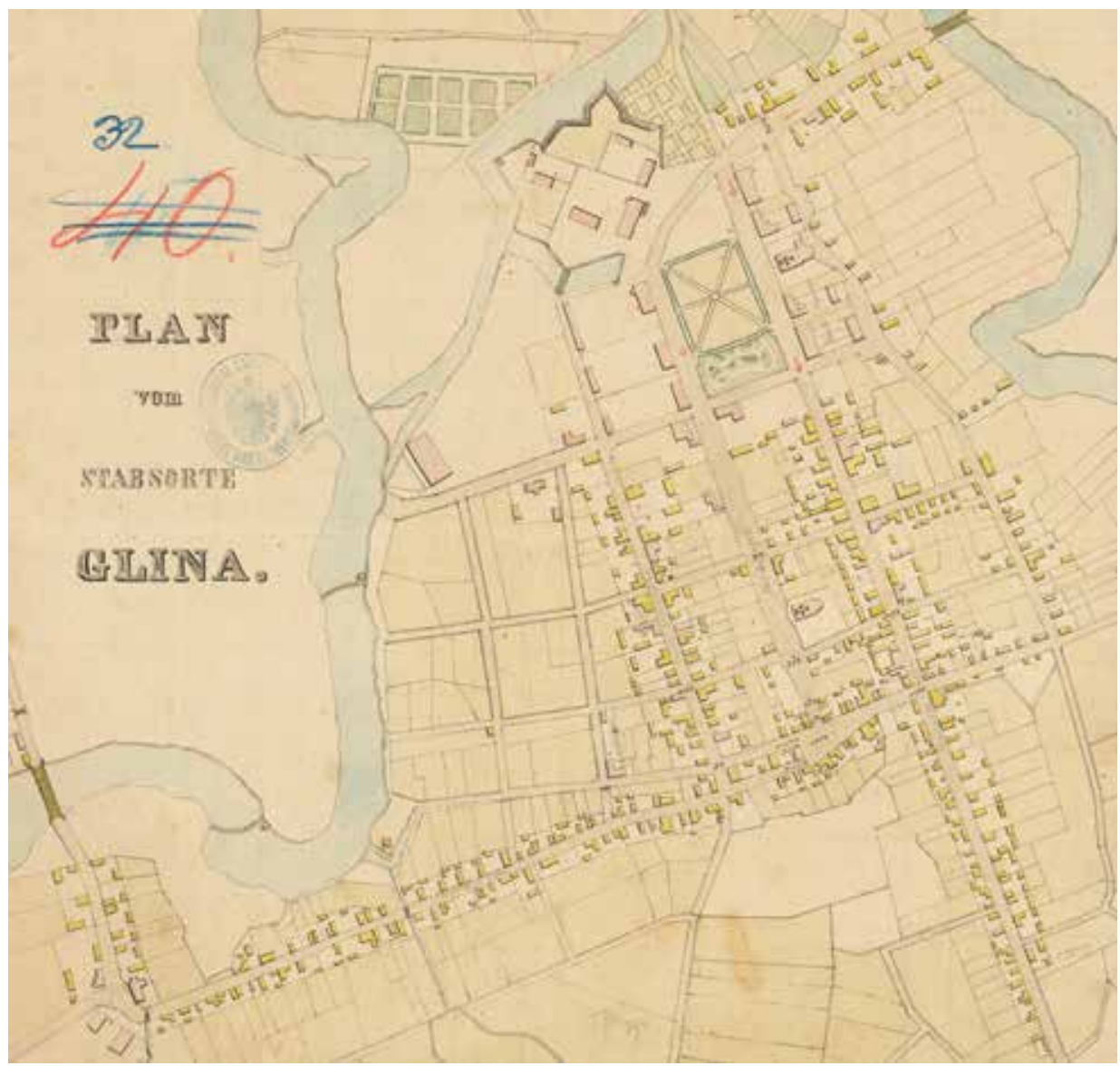

8. Plan Gline, 1860. (Hrvatski državni arhiv, Zagreb)

Map of Glina, 1860

crkve sv. Ivana Nepomuka. Nekadašnje pružanje bedema izgrađenog između rijeka može se djelomično predočiti ako uzmemo u obzir činjenicu da se nalazio paralelno uz današnju Ulicu kralja Tomislava, koja se već u 18. stoljeću razvila njegovom dužinom uz blagi odmak prema sjeveru. Park je zadržao svoj oblik i prostorne granice, ali je negacijom utvrde te zamjenom starijih objekata uz njegove rubove neskladnim interpolacijama izgubio niz svojih urbanističkih kvaliteta koje je sadržavao kao poveznica utvrde i naselja. ${ }^{46}$ Također, novom regulacijom tokova rijeka Gline i Maje krajem 19. stoljeća uklonjeno je glavno prirodno obilježje koje je utjecalo na prostorno oblikovanje naselja. Mreža osnovnih prometnica i ortogonalni raster ulica sačuvani su u gotovo neizmijenjenom obliku te prepoznati kao najveća vrijednost u zaštiti kulturnopovijesne cjeline današnjega grada. Prostorno-urbanistička, a pogotovo arhitektonska slika Gline tijekom 20. stoljeća znatno je narušena velikim razaranjima tijekom Domovinskog rata. Velik broj građevina u gradu napušten je i ostavljen propadanju ili nikada nije adekvatno obnovljen. Ono što se uspjelo obnoviti nakon rata, kao i brojni neodržavani i napušteni objekti, oštećeno je tijekom katastrofalnog potresa koji je 29. prosinca 2020. godine pogodio Petrinju, Sisak, Glinu i okolicu. U najvećoj mjeri stradala je upravo izgradnja na području povijesne jezgre i uz glavne prometnice. Rasprava o najučinkovitijem pristupu obnovi uključuje vrlo važno i složeno pitanje postupanja s oštećenim kulturnim dobrima i narušenom urbanom povijesnom cjelinom. Nakon desetljeća sustavne zapostavljenosti, otvara se prilika da se sveobuhvatnim pristupom u obnovu uključi primjerena zaštita i mogućnost nove prezentacije povijesnih i kulturnih vrijednosti grada. Postojeće vrijednosti valjalo bi sačuvati, oštećene građevine obnoviti, a one davno zanemarene prezentirati i prenamijeniti. Time bi se unaprijedila kvaliteta toga područja i života građana te omogućilo ispravno vrednovanje svih povijesnih slojeva i logike razvoja današnjega grada u kojemu graditeljski elementi 18. i prve polovice 19. stoljeća imaju ključnu ulogu. 


\section{Bilješke}

${ }^{\star}$ Ovaj rad nastao je u sklopu istraživanja na znanstvenom projektu Eugen Savojski (1663. - 1736.) i gradovi-tvrđave jugoistočne granice Habsburške Monarhije (HRZZ-IP-2018-01-3844), koji financira Hrvatska zaklada za znanost.

1

Povijest Gline i okolnog područja obrađena je u opsežnom zborniku: Glina. Glinski kraj kroz stoljeća (ur. Drago Roksandić - Mira Kolar-Dimitrijević), Glina, 1988. Radovi unutar zbornika koji se bave povijesno-prostornim razvojem Gline tijekom 18. i 19. stoljeća, a koji su predstavljali temeljno polazište ovog članka: MILAN KRUHEK, Fortifikacijska arhitektura Vojne krajine na području današnje općine Glina, 23-30; IVO MAROEVIĆ, Prostorni razvitak gradskog naselja Glina, 432-439; ĐURĐICA CVITANOVIĆ, Sakralna arhitektura - riznica umjetničke baštine glinskog kraja, 499-504. Drugi najopsežniji pregled glinske povijesti, koji treba čitati s oprezom zbog čestih nepotpunih podataka: MIJO DUKIĆ, Glina i okolica, Glina, 1980. Krajem 20. i početkom 21. stoljeća glinskom urbanističkom i arhitektonskom poviješću bavili su se: KSENIJA PETRIĆ, Prostor glinske utvrde u kojoj je održan Sabor godine 1737., Državnost. Casopis za politiku, znanost, kulturu $i$ gospodarstvo, 1 (1997.), 343-350; ANDREJ ŽMEGAČ, Bastioni kontinentalne Hrvatske: prilog poznavanju fortifikacijskoga graditeljstva u Hrvatskoj od 16. do 18. stoljeća, Zagreb, 2000., 46-49, 102; ANDREJA ROM, Urbanizam i arhitektura Gline do Prvog svjetskog rata, diplomski rad, Filozofski fakultet Sveučilišta u Zagrebu, 2010.

2

Sve do pada Bosne 1463. godine hrvatske su zemlje uglavnom bile zaštićene od osmanske opasnosti. Otad pa sve do početka (Velikog) Bečkog rata 1683. godine, osmanski napadi i njihov cilj što dubljeg prodora u Europu uvelike će opustošiti i smanjiti hrvatski teritorij.

3

Tijekom Bečkog rata (1683. - 1699.) vojske Habsburške Monarhije, Mletačke Republike, Poljske i Rusije, ujedinjene u Svetu ligu, nanijele su niz poraza Osmanskom Carstvu. Ubrzo nakon odlučujuće bitke kod Sente 1697. godine i pobjede carske vojske kojom je zapovijedao Eugen Savojski, potpisan je mir u Srijemskim Karlovcima kojim je Habsburška Monarhija stekla cijelu Ugarsku i Transilvaniju osim Temišvarskog Banata, cijelu Slavoniju i veći dio Srijema te Hrvatsku do Une i južno od Velebita.

4

Graditeljska aktivnost početkom 18. stoljeća pretežno je usmjerena prema fortifikacijama na jugoistočnoj granici Habsburške Monarhije (Osijek, Slavonski Brod, Stara Gradiška, Kostajnica).

5

Kapetanija je nazvana prema porječju rijeke Gline, a ne prema utvrdi ili naselju Glina, što bi se dalo naslutiti iz njezina imena. Više o povijesnom razvoju Svračice u: MILAN KRUHEK, Stari glinski gradovi i utvrde, Zagreb, 1987., 12-17.

\section{6}

Prostor oko ušća Maje u Glinu u povijesnim izvorima prvi put se spominje 1211. godine kao Vulkanova zemlja, dok se toponim Glina (terra de Glyna) prvi put spominje u kupoprodajnom ugovoru Zagrebačkog kaptola iz 1284. godine. Sve do osmanskih pustošenja cijelo glinsko područje nalazilo se u sastavu vlastelinstva topuske opatije. Više o razvoju glinskog kraja u: JOSIP ADAMČEK, Glina i njezina okolica u srednjem vijeku, u: Glina. Glinski kraj kroz stoljeća (bilj. 1), 13-21; MILAN KRUHEK (bilj. 5).

\section{7}

Iscrpno objašnjenje ove tvrdnje u: JOSIP ADAMČEK (bilj. 6), 13-15; MILAN KRUHEK (bilj. 5), 18-22.

8

MILAN KRUHEK (bilj. 5), 22.

9

MILAN KRUHEK (bilj. 5), 22-25.

10

MILAN KRUHEK (bilj. 5), 25.

11

Godine 1737. Habsburška Monarhija kao ruska saveznica uključuje se u Rusko-turski rat (1735. - 1739.). Sklapanjem mira u Beogradu 1739. godine, Monarhija je izgubila sjeverne dijelove Bosne i Srbije stečene prijašnjim Požarevačkim mirom, dok su granice ponovno uređene tokovima rijeka Dunava, Save i donjim tokom rijeke Une.

12

Zbog nepovoljnog tijeka novoga habsburško-osmanskog rata, a u skladu s planiranom obrambenom ulogom i blizinom novoizgrađene utvrde granici s Osmanskim Carstvom, na sjednici Hrvatskog sabora u Glini raspravljalo se o novim prilikama na granici, mogućnostima obrane tog kraja, isplati plaće vojnicima te isplati duga graditelju Du Portalu za njegove poslove na gradnji utvrda u Glini i Kostajnici. MILAN KRUHEK (bilj. 5), 26.

13

Österreichische Nationalbibliothek, Beč (dalje: ÖNB), FKB HH.114.1 KAR MAG. Reprodukcija jedinoga starijeg, dosad objavljenog prikaza, nalazi se u: MILAN KRUHEK (bilj. 1), 24. Autor je izostavio podatak o arhivskom izvoru. Plan prikazuje utvrdu, zvjezdasti šanac i dio okoline 1743. godine i ne donosi ništa drukčije niti novo u odnosu na plan prikazan u članku. Du Portalov nacrt utvrde dosad nije pronađen.

14

MILAN KRUHEK (bilj. 5), 27.

15

U znanstvenoj literaturi iznosi se suprotno vrednovanje utvrde. Tako Kruhek opravdava samu ideju izgradnje nove utvrde na području Banske krajine, no ne slaže se s njenom lokacijom, planom, niti krajnjom izvedbom. Navodi da je ona »sa stanovišta ratne arhitekture promašena investicija «. Za razliku od njega, Žmegač utvrdu promatra u drukčijem svjetlu novih eksperimentalnih ideja koje su »iskorak prema jednom od budućih tipova obrane«. MILAN KRUHEK (bilj. 1), 28; ANDREJ ŽMEGAČ (bilj. 1), 62-63.

16

Više o tome u: ALEXANDER BUCZYNSKI, Gradovi Vojne Krajine. Knjiga prva, Zagreb, 1997., 15-17.

17

Početkom šezdesetih godina 18. stoljeća sjedište Prve banske pukovnije premješta se iz Kostajnice u Petrinju.

18

Österreichisches Staatsarchiv, Kriegsarchiv, Karten- und Plansammlung, Beč (dalje: OeStA/KA), Inl. CVII Glina No 1.

19

Više u: FEDOR MOAČANIN, Cehovske privilegije Banske krajine iz 1773., u: Glina. Glinski kraj kroz stoljeća (bilj. 1), 38-45. 
20

IVICA GOLEC, Cehovsko obrtništvo Banske krajine i vojnog komuniteta Petrinja (1777. - 1871.), Povijesni prilozi, 22 (2002.), 109.

21

MIJO DUKIĆ (bilj. 1), 94.

22

Više u: ALEXANDER BUCZYNSKI (bilj. 16), 17-23.

23

Zakoni i propisi prema kojima su se vojni komuniteti razlikovali od ostalih mjesta Vojne krajine, ponajprije u vezi povlastica, uprave, financiranja, pravosuđa i gospodarskih poslova, prilagodavali su se stalnim mijenama organizacijske strukture Krajine tijekom druge polovice 18. stoljeća. Najveći utjecaj u upravljanju komunitetima imala je habsburška vojna vlast, zbog čije stalne kontrole i ograničenja, komuniteti nisu mogli u potpunosti ostvariti svoj razvojni potencijal i planiranu ulogu nositelja financijske stabilnosti Vojne krajine. Više u: ALEXANDER BUCZYNSKI, Nastanak i organizacijski oblik vojnih komuniteta od 1748. do 1850., Arhivski vjesnik, 34-35 (1991.-1992.), 185-194.

24

ALEXANDER BUCZYNSKI (bilj. 16), 137, 141.

25

OeStA/KA, z.B B „IXa 242“.

26

Hrvatski državni arhiv, Zagreb (dalje: HR-HDA), Kartografska zbirka, HR-HDA-902, B.III.23.

27

IVO MAROEVIĆ (bilj. 1), 433.

28

Prije izgradnje kapele vjerski obredi održavali su se u jednom objektu unutar utvrde. Nova kapela bila je čvrsto zidana građevina s tri oltara. ĐURĐICA CVITANOVIĆ, Sakralna arhitektura baroknog razdoblja. Gorički i gorsko-dubički arhiđakonat, Zagreb, 1985., 276.

29

Prema odluci Marije Terezije od 24. kolovoza 1764. godine u svakom štapskom mjestu regimente trebala se organizirati škola. Iste godine u Glini je proradila prva škola, koja će sve do 1774. godine biti jedina njemačka škola na području Prve banske regimente. Godine 1770 . imala je 116, a iduće godine 101 polaznika. IVAN JURIŠIĆ, Školstvo u Prvoj banskoj regimenti do 1848. godine, s posebnim osvrtom na srpske narodne škole, u: Glina. Glinski kraj kroz stoljeća (bilj. 1), 58

30

OeStA/KA, GIh-195.

31

MILAN KRUHEK (bilj. 1), 27.

32

HR-HDA-904, Zbirka planova, Inv. br. 55.

33

Kompleks Hotela Casino sastoji se od starije građevine, Narodne gostione, sagrađene u prvoj polovici 19. stoljeća i novije reprezentativne jednokatnice izgrađene južno uz gostionicu početkom 20. stoljeća. Kompleks je zaštićeno kulturno dobro i danas služi kao glavno okupljalište Glinjana. Stara gostionica služi kao hotel, a kasnije prigrađeni objekt kao restoran i kafić.

34

Hortikulturnom uređenju naselja za vrijeme svog boravka u Glini od 1809. do 1814. godine znatno je doprinio francuski pukovnik Etienne Jolly. MIJO DUKIĆ (bilj. 1), 93.

35

ÖNB, FKB C.101.a.2 KAR MAG.

36

HR-HDA-902, Kartografska zbirka, E.V.131.

37

MIJO DUKIĆ (bilj. 1), 91.

38

O crkvi sv. Ivana Nepomuka Bartola Felbingera vidjeti: ĐURĐICA CVITANOVIĆ (bilj. 28), 276-277.

39

Felbingerova crkva visoke arhitektonske, urbanističke i povijesne vrijednosti u potpunosti je razorena tijekom Domovinskog rata. Nova crkva izgrađena je tek 2000. godine na novoj lokaciji uza staro sajmište na mjestu nekadašnjih jugozapadnih bedema utvrde. Temelji nekadašnje crkve sačuvani su i prezentirani kao memorijalno mjesto.

40

Ime ulice vjerojatno je proizišlo iz brojnosti stanovnika pravoslavne zajednice koji su u njoj živjeli. Pravoslavna crkva Rođenja Bogorodice nalazila se u paralelnoj ulici prema istoku, a drvena kapela sv. Đurđa iz 18. stoljeća u paralelnoj ulici prema zapadu. Valja istaknuti kako je u Glini prema podatcima iz 1811. godine udio muškoga pravoslavnog stanovništva iznosio 56,50 \%, dok je udio pripadnika pravoslavne zajednice u cjelokupnom stanovništvu Prve banske pukovnije 1810. godine iznosio 65,66 \%. DRAGO ROKSANDIĆ, Između imaginacije i realnosti. Prva banska regimenta u prvoj polovini 19. stoljeća, u: Glina. Glinski kraj kroz stoljeća (bilj. 1), 52.

41

Vidljivi su ostatci zapadne redute i prvoga trokutastog istaka od istoka.

42

U broj stanovnika nije uključeno štapsko osoblje. Vidi: DRAGO ROKSANDIĆ (bilj. 40), 51.

43

DRAGO ROKSANDIĆ (bilj. 40), 58.

44

Zidane kuće označene su ružičastom, drvene žutom, oranice smeđom i vrtovi zelenom bojom.

45

Crkva je uništena u kolovozu 1941. godine, a danas se na tom mjestu nalazi Hrvatski dom s gradskom knjižnicom. Cijelo memorijalno područje, zajedno s brončanim spomenikom Antuna Augustinčića Majka i dijete, danas je zaštićeno kulturno dobro. Nova crkva sagrađena je 1963. godine u današnjoj Hrvatskoj ulici. Više o crkvi: MARKO MILJANOVIĆ, Bogorodičina crkva u Glini, u: Glina. Glinski kraj kroz stoljeća (bilj. 1), 504-512.

46

IVO MAROEVIĆ (bilj. 1), 436. 


\section{Summary}

\section{Iva Vidović}

\section{The Fortress and Town of Glina from the $18^{\text {th }}$ to the mid-19 $19^{\text {th }}$ Century, as Recorded in the Cartographic Sources}

The history of today's town of Glina begins in the 1730s, when due to the threat of a new Habsburg-Ottoman war, the newly formed borderline on the river Una and its hinterland were reinforced by constructing new and reconstructing old fortifications. In order to defend the Banal Military Frontier (Krajina), the Croatian-Slavonian-Dalmatian Ban Josip Esterházy needed a skilled fortification builder and Emperor Charles sent the Frenchman Felix Du Portal de Monteau to the frontier area, who in 1735 proposed the construction of a new frontier fortress at the point where the Maja flows into the Glina river. The modest bastion fortress with an unusual ground plan and other parts of the fortification system were mostly completed in 1736, and in 1745 they took on the recognizable form that they have retained to the present day. In the middle of the century, a military-civilian town started to take shape between the fortress and the ramparts stretching south of the fort, between the meanders of the two rivers. Glina flourished in the second half of the $18^{\text {th }}$ century due to the large population influx and the intensification of crafts and trade. It was at that time that the almost regular orthogonal grid was created that forms the core of today's town. The steady economic, demographic, and spatial development of Glina continued even more intensely during the first half of the $19^{\text {th }}$ century. Its defensive structures completely lost their importance and were assimilated within the new spatial organization, in which the main urban accents included the central park surrounded by late Baroque and Classicist military and housing edifices with the Roman Catholic and Eastern Orthodox churches.

During the $18^{\text {th }}$ and the first half of the $19^{\text {th }}$ century, Glina advanced from a modest frontier fortress with considerable strategic importance to a completely new town that soon took on urban features, with a grid of roads and streets that define it to the present day. The fortress of Glina, with its simple design and modest size, is not a significant achievement of bastion architecture, but its role as the core of today's town is crucial. In addition to the fortress, the spatial identity of today's Glina is defined by the ramparts, the central park, the specific landscape features, and valuable individual buildings. Unfortunately, most of these assets have been largely devastated by new, inconsistent constructions during the $20^{\text {th }}$ century, wars, the recent earthquake in Banovina, and the systematic economic neglect of the area. Therefore, the aim of this paper is to expand and supplement our knowledge about the historical and spatial development of Glina with new insights, as well as to contribute to its urban renewal and the revitalization of its historical core.

Keywords: Glina, fortress, town, historical and spatial development, cartographic sources, $18^{\text {th }}$ century, first half of the $19^{\text {th }}$ century 